\title{
Fabrication and Characterization of Copper System Compound Semiconductor Solar Cells
}

\author{
Ryosuke Motoyoshi, Takeo Oku, Atsushi Suzuki, Kenji Kikuchi, \\ Shiomi Kikuchi, Balachandran Jeyadevan, and Jhon Cuya \\ Department of Materials Science, The University of Shiga Prefecture, 2500 Hassaka, Hikone, Shiga 522-8533, Japan \\ Correspondence should be addressed to Takeo Oku, oku@mat.usp.ac.jp
}

Received 19 March 2010; Revised 14 June 2010; Accepted 12 July 2010

Academic Editor: Meilin Liu

Copyright (C) 2010 Ryosuke Motoyoshi et al. This is an open access article distributed under the Creative Commons Attribution License, which permits unrestricted use, distribution, and reproduction in any medium, provided the original work is properly cited.

Copper system compound semiconductor solar cells were produced by a spin-coating method, and their cell performance and structures were investigated. Copper indium disulfide- (CIS-) based solar cells with titanium dioxide $\left(\mathrm{TiO}_{2}\right)$ were produced on F-doped $\mathrm{SnO}_{2}$ (FTO). A device based on an $\mathrm{FTO} / \mathrm{CIS} / \mathrm{TiO}_{2}$ structure provided better cell performance compared to that based on $\mathrm{FTO} / \mathrm{TiO}_{2} / \mathrm{CIS}$ structure. Cupric oxide- $(\mathrm{CuO}-)$ and cuprous oxide- $\left(\mathrm{Cu}_{2} \mathrm{O}-\right)$ based solar cells with fullerene $\left(\mathrm{C}_{60}\right)$ were also fabricated on FTO and indium tin oxide (ITO). The microstructure and cell performance of the $\mathrm{CuO} / \mathrm{C}_{60}$ heterojunction and the $\mathrm{Cu}_{2} \mathrm{O}: \mathrm{C}_{60}$ bulk heterojunction structure were investigated. The photovoltaic devices based on $\mathrm{FTO} / \mathrm{CuO} / \mathrm{C}_{60}$ and $\mathrm{ITO} / \mathrm{Cu}_{2} \mathrm{O}: \mathrm{C}_{60}$ structures provided short-circuit current density of $0.015 \mathrm{mAcm}^{-2}$ and $0.11 \mathrm{mAcm}^{-2}$, and open-circuit voltage of $0.045 \mathrm{~V}$ and 0.17 $\mathrm{V}$ under an Air Mass 1.5 illumination, respectively. The microstructures of the active layers were examined by X-ray diffraction and transmission electron microscopy.

\section{Introduction}

Chalcopyrite semiconductors are expected as one of the alternative materials to silicon solar cells. The features of chalcopyrite semiconductors include high optical absorption efficiency, low light degradation, and high radiation resistance. Copper indium disulfide, $\mathrm{CuInS}_{2}$ (CIS) is a wellknown p-type chalcopyrite semiconductor. CIS is a suitable material for high-efficiency solar cells because its bandgap $(1.5 \mathrm{eV})$ is close to the ideal energy gap, which is well matched with the solar spectrum. In addition, the band structure shows direct transition, which provides a high efficiency. The highest efficiency of $12 \%$ as the absorber layer has been obtained for the CIS solar cells by using the expensive vacuum evaporation technique [1]. Most of the efficient CISbased solar cells have been prepared by using CdS as buffer layers.

Cd-free CIS-based solar cells with $\mathrm{TiO}_{2}$ and $\mathrm{In}_{2} \mathrm{O}_{3}$ have been fabricated by an evaporation method [2-4] and reported to show efficiencies of $3 \sim 9.5 \%$ [3, 4]. Titanium dioxide $\left(\mathrm{TiO}_{2}\right)$ as an n-type semiconductor has also been used as electrode materials for dye-sensitized solar cells [5]. $\mathrm{TiO}_{2}$ is also a safe and low-cost material for environmentally harmonized solar cells. A low-cost method is essential for the mass production of CIS-based solar cells, and spin coating is a more economical method compared with vacuum evaporation [6-8]. CIS thin films deposited by sol-gel spin-coating methods have also been investigated and reported $[9,10]$. The resulting structure closely resembles that of polymeric bulk heterojunction cells (polymer/ $\mathrm{C}_{60}$ ) fabricated using organic materials [11-13]. The bulk heterojunction structures contribute to increase the $\mathrm{p}-\mathrm{n}$ heterojunction interface for photoelectric conversion region in the devices. The aim of the present work was to investigate whether the $\mathrm{TiO}_{2} / \mathrm{CIS}$ structure by penetration of CIS nanocrystals into the porous $\mathrm{TiO}_{2}$ layer could function as a bulk heterojunction structure.

Oxide semiconductors are one of the alternatives to silicon solar cells. Features of oxide semiconductors are high optical absorption and low cost of raw materials. Copper oxides $\left(\mathrm{CuO}\right.$ and $\left.\mathrm{Cu}_{2} \mathrm{O}\right)$ are well-known p-type 


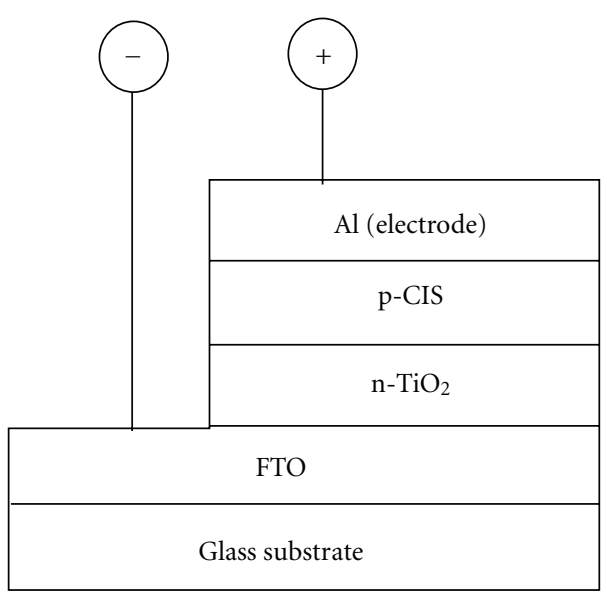

(a)

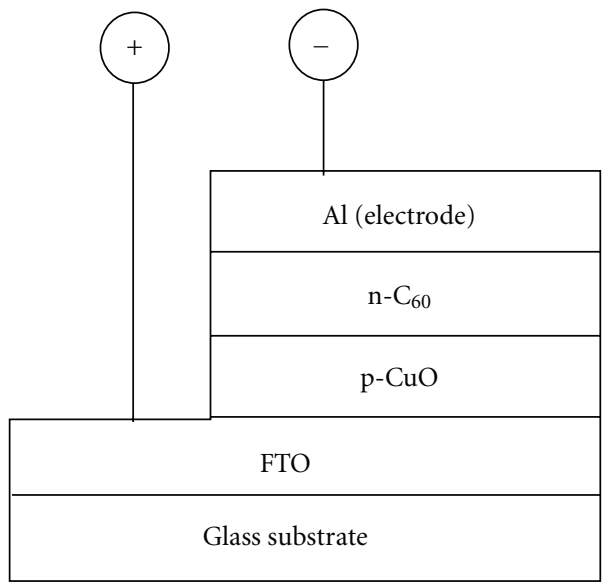

(c)

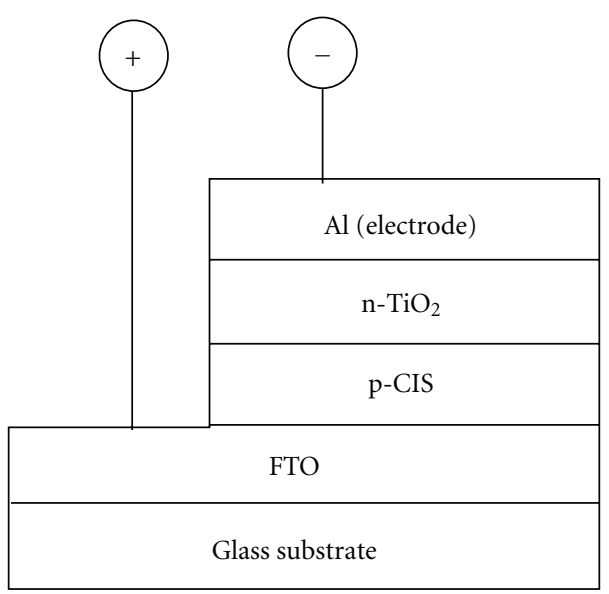

(b)

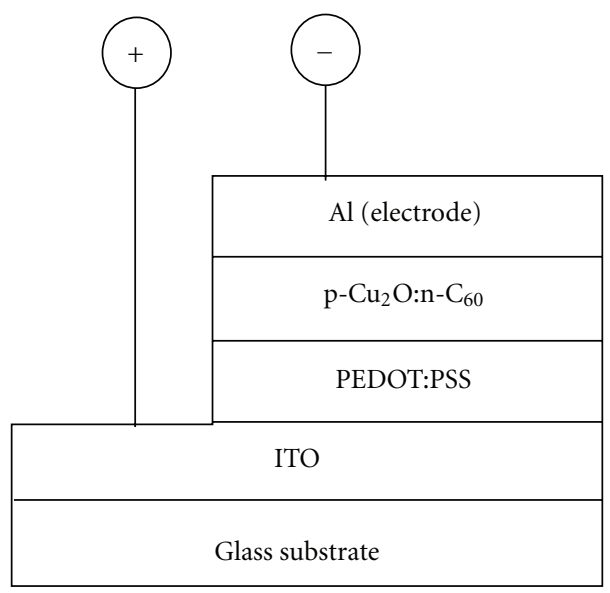

(d)

Figure 1: Structures of (a) $\mathrm{FTO} / \mathrm{TiO}_{2} / \mathrm{CIS} / \mathrm{Al}$, (b) $\mathrm{FTO} / \mathrm{CIS} / \mathrm{TiO}_{2} / \mathrm{Al}$, (c) $\mathrm{FTO} / \mathrm{CuO} / \mathrm{C}_{60} / \mathrm{Al}$ heterojunction solar cells, and (d) ITO/PEDOT:PSS/ $\mathrm{Cu}_{2} \mathrm{O}: \mathrm{C}_{60} / \mathrm{Al}$ bulk heterojunction solar cells.

oxide semiconductors. $\mathrm{CuO}$ and $\mathrm{Cu}_{2} \mathrm{O}$ are suitable materials for high-efficiency solar cells because those direct bandgaps $(\sim 1.5 \mathrm{eV}$ and $\sim 2.0 \mathrm{eV})$ are close to the ideal energy gap for solar cells, and are well matched with the solar spectrum. The highest efficiency of $\sim 2 \%$ has been obtained for $\mathrm{Cu}_{2} \mathrm{O}$ solar cells by using a high-temperature annealing method and an expensive vacuum evaporation technique [14]. Heterojunction solar cells with $\mathrm{Cu}_{2} \mathrm{O}$ and $\mathrm{ZnO}$ have been fabricated by electrodeposition and photochemical deposition methods [15-17], and an efficiency of $\sim 0.001 \%$ was reported [17]. However, $\mathrm{p}$-n heterojunction interface area for photoelectric conversion is small. One of improvements is to increase the $\mathrm{p}-\mathrm{n}$ heterojunction interface by blending of $\mathrm{p}$-type and $\mathrm{n}$ type semiconductors, which are called bulk heterojunction solar cells [6-8]. Although $\mathrm{CuO}$ is used as a hole transfer layer and a barrier layer for dye-sensitized solar cells $[18,19]$, few solar cells with $\mathrm{CuO}$ used as a p-type semiconductor active layer have been investigated. The advantage of $\mathrm{CuO}$ is a simple production method.

Fullerene $\left(\mathrm{C}_{60}\right)$ is a good acceptor material for solar cells, and has been used as n-type semiconductor active layer for organic thin film solar cells $[12,20]$. A low-cost method is essential for mass production of CuO-based solar cells, and spin coating is a more economical method compared to vacuum evaporation $[6,7]$. $\mathrm{CuO}$ thin films deposited by sol-gel spin-coating methods have also been investigated and reported [21].

The purpose of the present work was to prepare copper-based semiconductor solar cells by using a spincoating method, and to investigate the microstructures and photovoltaic properties for $\mathrm{TiO}_{2} / \mathrm{CIS}$ and $\mathrm{CuO} / \mathrm{C}_{60}$ and $\mathrm{Cu}_{2} \mathrm{O}: \mathrm{C}_{60}$ structures. The solar cells were investigated by microstructure analysis, optical absorption, and electronic property measurements.

\section{Experimental Procedures}

2.1. Fabrication of Dioxide/Copper Indium Disulfide Solar Cells. Two types of solar cells with $\mathrm{TiO}_{2} / \mathrm{CIS}$ and $\mathrm{CIS} / \mathrm{TiO}_{2}$ structures were fabricated as shown in Figures 1(a) and 1(b), respectively. $\mathrm{TiO}_{2}$ and CIS layers were coated on precleaned F-doped $\mathrm{SnO}_{2}$ (FTO) glass plates (Asahi Glass, $\sim 9.3 \Omega / \square$ ) by 
TABLE 1: Measured parameters of solar cells.

\begin{tabular}{lcccc}
\hline Layered samples & $\mathrm{FTO} / \mathrm{TiO}_{2} / \mathrm{CIS} / \mathrm{Al}$ & $\mathrm{FTO} / \mathrm{CIS} / \mathrm{TiO}_{2} / \mathrm{Al}$ & $\mathrm{FTO} / \mathrm{CuO} / \mathrm{C}_{60} / \mathrm{Al}$ & $\mathrm{ITO} / \mathrm{PEDOT}: \mathrm{PSS} / \mathrm{Cu}_{2} \mathrm{O}: \mathrm{C}_{60} / \mathrm{Al}$ \\
\hline$V_{\mathrm{OC}}(\mathrm{V})$ & $1.1 \times 10^{-3}$ & 0.010 & 0.045 & 0.17 \\
$J_{\mathrm{SC}}\left(\mathrm{mA} / \mathrm{cm}^{2}\right)$ & $3.6 \times 10^{-4}$ & $6.0 \times 10^{-3}$ & 0.015 & 0.11 \\
$\mathrm{FF}$ & 0.25 & 0.25 & 0.25 & 0.23 \\
$\eta(\%)$ & $1.0 \times 10^{-7}$ & $1.5 \times 10^{-5}$ & $1.7 \times 10^{-4}$ & $4.3 \times 10^{-3}$ \\
\hline
\end{tabular}

using a spin-coating method. $\mathrm{TiO}_{2}$ layers with a thickness of $\sim 10 \mu \mathrm{m}$ were prepared by squee-gee coating using a $\mathrm{TiO}_{2}$ paste $(0.6 \mathrm{~g} / \mathrm{mL})$ of fine $\mathrm{TiO}_{2}$ powders (P25, Sigma Aldrich) in an acetylacetone/polyethylene glycol solution and were annealed at $450^{\circ} \mathrm{C}$ for 30 minutes in air [22]. Copper acetate monohydrate, $\mathrm{Cu}\left(\mathrm{CH}_{3} \mathrm{COO}\right)_{2} \cdot \mathrm{H}_{2} \mathrm{O}(0.5 \mathrm{~mol} / \mathrm{L}$, Sigma Aldrich, 99.99\%) and indium acetate, $\mathrm{In}\left(\mathrm{CH}_{3} \mathrm{COO}\right)_{3}$ (0.5 mol/L, Sigma Aldrich, 99.99\%) were dissolved into 2propanol/monoethanolamine with a ratio of $4: 1$ and 1propanol/diethanolamine with a ratio of $4: 1$, respectively, and the two solutions were then mixed. The molar ratio of $\mathrm{Cu}$ :In was $1: 1$. Cu-In layers of CIS precursor substance were prepared by spin coating at $1000 \mathrm{rpm}$ using a mixed $\mathrm{Cu}-\mathrm{In}$ solution. The $\mathrm{Cu}$-In films were annealed at $200^{\circ} \mathrm{C}$ under an $\mathrm{N}_{2}$ atmosphere for 30 minutes. The films were sulfurated by dipping in sulfur solution $(1.0 \mathrm{~mol} / \mathrm{L})$ in $o$-dichlorobenzene. After annealing at $500^{\circ} \mathrm{C}$ for 30 minutes. in a $\mathrm{N}_{2}(95 \%) / \mathrm{H}_{2}$ (5\%) mixture gas, CIS layers with a thickness of $\sim 100 \mathrm{~nm}$ were formed from the $\mathrm{Cu}$-In films.

2.2. Fabrication of Copper Oxide/Fullerene Solar Cells. $\mathrm{CuO}$ and $\mathrm{C}_{60}$ layers were coated on precleaned FTO glass plates (Asahi Glass, $\sim 9.3 \Omega / \square$ ) by using a spin-coating method. Copper acetate monohydrate, $\mathrm{Cu}\left(\mathrm{CH}_{3} \mathrm{COO}\right)_{2} \cdot \mathrm{H}_{2} \mathrm{O}$ (0.5 mol/L, Sigma Aldrich, 99.99\%) was dissolved into 2propanol/monoethanolamine. $\mathrm{Cu}$ layers of $\mathrm{CuO}$ precursor substance were prepared by spin coating at $1000 \mathrm{rpm}$ using the mixture $\mathrm{Cu}$ solution. After annealing at $300^{\circ} \mathrm{C}$ under air atmosphere for 3 hours, $\mathrm{CuO}$ layers with a thickness of $\sim 100 \mathrm{~nm}$ were formed from the $\mathrm{Cu}$ (II) films. $\mathrm{C}_{60}$ layers with a thickness of $\sim 100 \mathrm{~nm}$ were prepared on a $\mathrm{CuO}$ layer by spin coating using a $\mathrm{C}_{60}$ solution $(16 \mathrm{mg} / \mathrm{mL})$ with $\mathrm{C}_{60}$ powders (Material Technologies Research, 99.98\%) in $o$ dichlorobenzene, and were annealed at $100^{\circ} \mathrm{C}$ for 30 minutes in $\mathrm{N}_{2}$ atmosphere.

$\mathrm{Cu}_{2} \mathrm{O}$ nanoparticles were synthesized by reducing copper-amine complex with 1-heptanol in the presence of tetramethyl ammonium hydroxide. The details of the synthesis scheme were as follows: Copper acetate and oleylamine were introduced into 1-heptanol and heated under a nitrogen atmosphere at $120^{\circ} \mathrm{C}$ for one hour to remove the moisture in the system. Then, tetramethyl ammonium hydroxide (TMAOH) dissolved in 1-hepatanol $\left(\sim 150^{\circ} \mathrm{C}\right)$ was introduced and the suspension was heated at $150^{\circ} \mathrm{C}$ for 2 hours. Next, the suspension was cooled to room temperature and $\mathrm{Cu}_{2} \mathrm{O}$ nanoparticles were recovered by centrifuging. Finally, the $\mathrm{Cu}_{2} \mathrm{O}$ nanoparticles were washed with methanol to remove excess oleylamine, and the $\mathrm{Cu}_{2} \mathrm{O}$ nanoparticles $(\sim 100 \mathrm{mg})$ were dispersed in toluene $(10 \mathrm{~mL})$.
A thin layer of polyethylenedioxythiophene doped with polystyrene-sulfonic acid (PEDOT:PSS) (Sigma Aldrich) was spin-coated at $2000 \mathrm{rpm}$ on precleaned indium tin oxide (ITO) glass plates (Geomatec Co., Ltd., $\sim 10 \Omega / \square$ ). After annealing at $100^{\circ} \mathrm{C}$ for 10 minutes in $\mathrm{N}_{2}$ atmosphere, semiconductor layers were prepared on a PEDOT layer by spin coating using a mixed solution of a toluene with $\mathrm{Cu}_{2} \mathrm{O}$ nanoparticle and a $\mathrm{C}_{60}$ solution $(16 \mathrm{mg} / \mathrm{mL})$ with $\mathrm{C}_{60}$ powders (Material Technologies Research, 99.98\%) in $o$ dichlorobenzene. The thickness of the bulk heterojunction structure was approximately $\sim 150 \mathrm{~nm}$. The $\mathrm{Cu}_{2} \mathrm{O}: \mathrm{C}_{60}$ layers were annealed at $100^{\circ} \mathrm{C}$ for 30 minutes in $\mathrm{N}_{2}$ atmosphere.

For all the present copper system compound semiconductor solar cells, aluminum (Al) metal contacts with a thickness of $\sim 100 \mathrm{~nm}$ were deposited as top electrodes, and annealed at $140^{\circ} \mathrm{C}$ for 20 minutes in $\mathrm{N}_{2}$ atmosphere. Schematic illustrations of the present solar cells are shown in Figure 1.

2.3. Measurements of Solar Cells. The current density-voltage $(J-V)$ characteristics (Hokuto Denko Corp., HSV-100) of the solar cells were measured both in the dark and under illumination at $100 \mathrm{~mW} / \mathrm{cm}^{2}$ by using an AM 1.5 solar simulator (San-ei Electric, XES-301S) in $\mathrm{N}_{2}$ atmosphere. The solar cells were illuminated through the side of the FTO and ITO substrates, and the illuminated area was $0.16 \mathrm{~cm}^{2}$. Optical absorption of the solar cells was investigated by means of UVvisible spectroscopy (Hitachi, Ltd., U-4100). The microstructures of the CIS, copper oxides, and $\mathrm{C}_{60}$ thin films were investigated by X-ray diffractometer (XRD, PHILIPS X'PertMPD System) with $\mathrm{CuK} \alpha$ radiation operating at $40 \mathrm{kV}$ and $40 \mathrm{~mA}$, scanning electron microscopy (SEM, Hitachi, Ltd., S-3200N), energy dispersive X-ray analysis (EDX, EMAX$5770 \mathrm{~W}$ ), and transmission electron microscopy (TEM) operating at $200 \mathrm{kV}$ (Hitachi, Ltd., H-8100).

\section{Results and Discussion}

3.1. $\mathrm{CIS} / \mathrm{TiO}_{2}$ Solar Cells. The $J-V$ characteristics of the $\mathrm{TiO}_{2} / \mathrm{CIS}$ and $\mathrm{CIS} / \mathrm{TiO}_{2}$ structures in the dark and under illumination were measured. The photocurrent was observed under illumination and both structures showed characteristic curves with open-circuit voltage and short-circuit current. The measured parameters of these solar cells are summarized in Table 1. A solar cell with the $\mathrm{CIS} / \mathrm{TiO}_{2}$ structure provided power conversion efficiency $(\eta)$ of $1.5 \times 10^{-5} \%$, fill factor (FF) of 0.25 , short-circuit current density $\left(J_{\mathrm{SC}}\right)$ of $6.0 \times$ $10^{-3} \mathrm{~mA} / \mathrm{cm}^{2}$, and open-circuit voltage $\left(V_{\mathrm{OC}}\right)$ of $1.0 \times 10^{-2} \mathrm{~V}$, which is better than those of the $\mathrm{TiO}_{2} / \mathrm{CIS}$ device. 


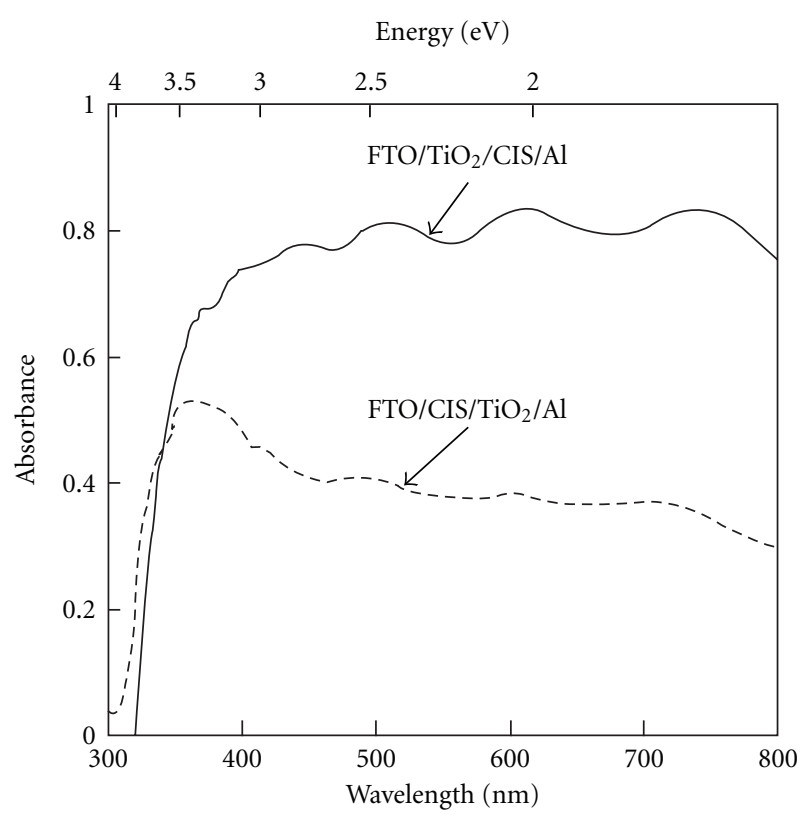

FIgUre 2: Optical absorption of $\mathrm{CIS} / \mathrm{TiO}_{2}$ heterojunction solar cells.

Figure 2 shows the measured optical absorption of the solar cells. The $\mathrm{TiO}_{2} / \mathrm{CIS}$ structure shows high absorption at $444,510,606$, and $738 \mathrm{~nm}$, which correspond to $2.8,2.4,2.0$, and $1.7 \mathrm{eV}$, respectively. The $\mathrm{CIS} / \mathrm{TiO}_{2}$ structure also shows high optical absorption at $420,488,590$, and $710 \mathrm{~nm}$, which correspond to 2.6, 2.5, 2.1, and $1.7 \mathrm{eV}$, respectively. The absorption peaks at $444 \mathrm{~nm}$ and $420 \mathrm{~nm}$ for the $\mathrm{TiO}_{2} / \mathrm{CIS}$ and CIS/TiO 2 structures were due to $\mathrm{TiO}_{2}$, and the other peaks were due to CIS. As shown in Figure 2, the optical absorption between $400 \mathrm{~nm}$ and $800 \mathrm{~nm}$ for the $\mathrm{TiO}_{2} / \mathrm{CIS}$ solar cell is higher than that of $\mathrm{CIS} / \mathrm{TiO}_{2}$ structure. The increase in film thickness of the CIS layer in the $\mathrm{TiO}_{2} / \mathrm{CIS}$ structure through the penetration of the CIS nanocrystals into the porous $\mathrm{TiO}_{2}$ layer results in the increase in the optical absorption of solar cells in the $\mathrm{TiO}_{2} / \mathrm{CIS}$ structure.

Microstructures of the CIS thin film were investigated by XRD, as shown in Figure 3(a). Diffraction peaks corresponding to CIS and indium oxide $\left(\mathrm{In}_{2} \mathrm{O}_{3}\right)$ were observed for the CIS thin film. The crystallite size was estimated using the Scherer equation: $D=0.9 \lambda / B \cos \theta$, where $\lambda, B$, and $\theta$ represent the wavelength of the X-ray source, the full width at half maximum (FWHM), and the Bragg angle, respectively [23]. From the FWHM of the 112 peak, the crystallite size of CIS was determined to be $13.1 \mathrm{~nm}$. Elemental analysis of the CIS thin film was investigated by SEM and EDX. The atomic concentrations of the CIS thin film were copper (28.0\%), indium $(26.0 \%)$ and sulfur $(46.0 \%)$.

Preparation conditions of the $\mathrm{TiO}_{2} / \mathrm{CIS}$ structure were different from those of the $\mathrm{CIS} / \mathrm{TiO}_{2}$ structure, and influence of different annealing temperatures of the $\mathrm{TiO}_{2}$ layer was investigated. Figures 3(b) and 3(c) show X-ray diffraction patterns of the $\mathrm{TiO}_{2}$ thin films on the glass substrates annealed at $450^{\circ} \mathrm{C}$ for 30 minutes in air, and $500^{\circ} \mathrm{C}$ for 30 minutes in $\mathrm{N}_{2} / \mathrm{H}_{2}$ atmosphere and annealed at $450^{\circ} \mathrm{C}$ for 30 minutes in air, respectively. The X-ray diffraction patterns

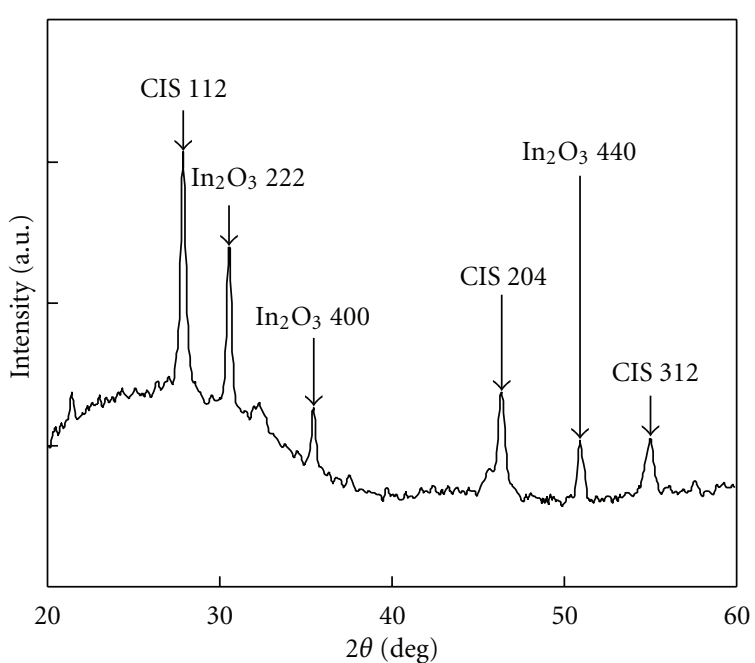

(a)

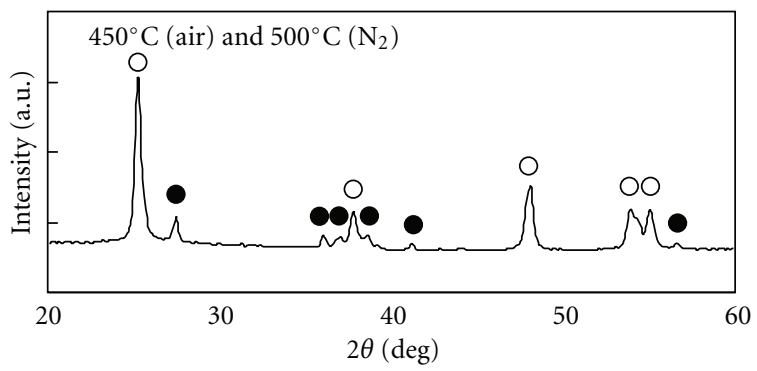

○ $\mathrm{TiO}_{2}$ (anatase)

- $\mathrm{TiO}_{2}$ (rutile)

(b)

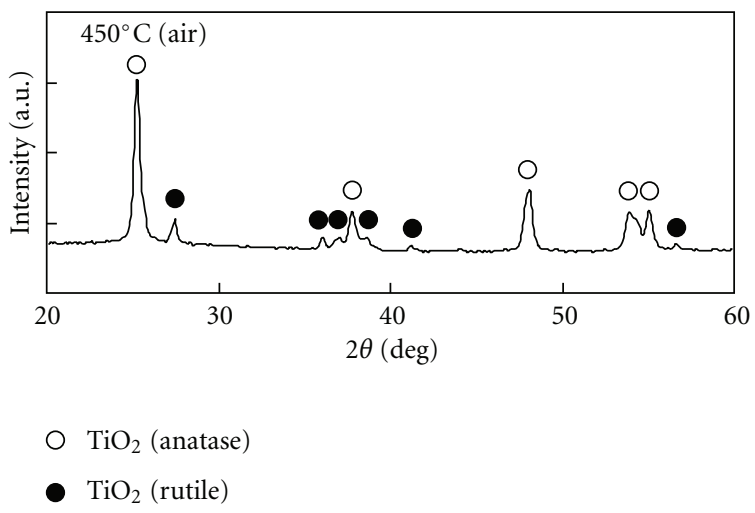

(c)

FIgure 3: XRD pattern of (a) CIS thin film and (b) $\mathrm{TiO}_{2}$ thin film annealed at $450^{\circ} \mathrm{C}$ for 30 minutes in air and $500^{\circ} \mathrm{C}$ for 30 minutes in $\mathrm{N}_{2} / \mathrm{H}_{2}$ atmosphere and (c) $\mathrm{TiO}_{2}$ thin film annealed at $450^{\circ} \mathrm{C}$ for 30 minutes in air.

indicate an anatase phase with a tetragonal system, and there was a slight amount of the rutile phase. The particle size of the anatase phase was estimated to be $26.1 \mathrm{~nm}$ from the Scherrer's equation. No differences between Figures 3(b) and $3(c)$ were observed on the crystalline structures of the $\mathrm{TiO}_{2}$ layer. 


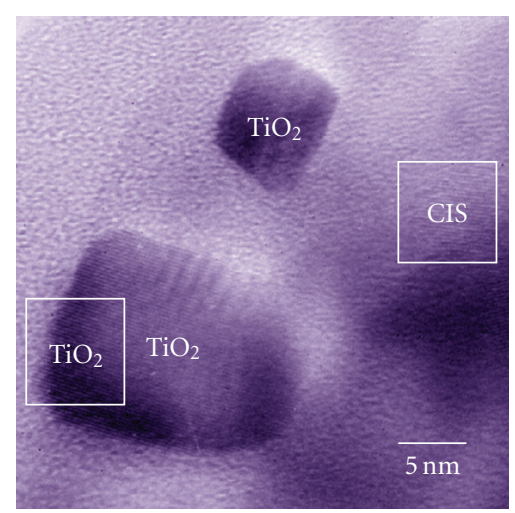

(a)

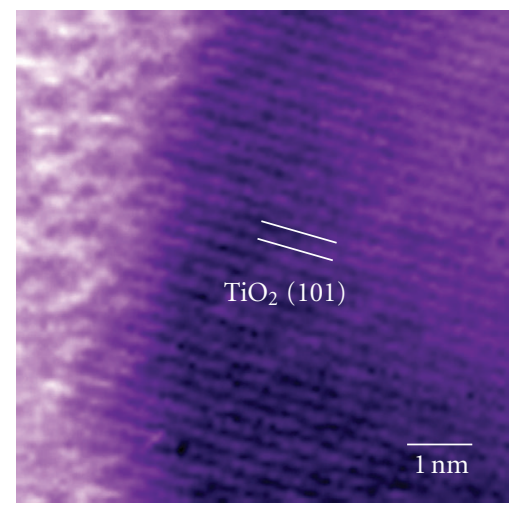

(c)

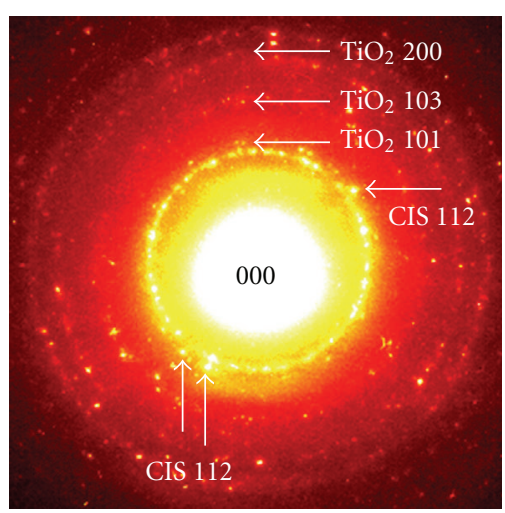

(b)

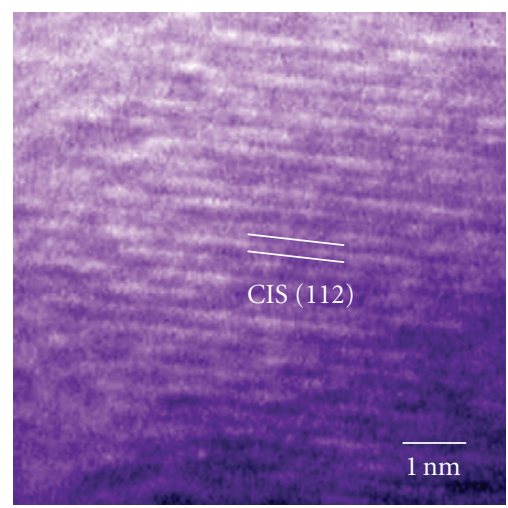

(d)

FIgure 4: (a) TEM image and (b) electron diffraction pattern of $\mathrm{TiO}_{2} / \mathrm{CIS}$ structure. (c) Enlarged $\mathrm{HREM}$ images of TiO ${ }_{2}$ in (a) and (d) CIS in (a).

Figures 4(a) and 4(b) show a TEM image and an electron diffraction pattern of the $\mathrm{TiO}_{2} /$ CIS composite film, respectively. The TEM image indicated $\mathrm{TiO}_{2}$ nanocrystals in the CIS matrix. Debye-Scherrer rings, which indicate polycrystalline structures of $\mathrm{TiO}_{2}$ and 112 reflection of the CIS crystal can be seen in Figure 4(b). Enlarged highresolution electron microscopy (HREM) images of the $\mathrm{TiO}_{2}$ and CIS in Figure 4(a) are shown in Figures 4(c) and 4(d), respectively, revealing the lattice fringes of the 101 of the $\mathrm{TiO}_{2}$ and the 112 of the CIS crystals.

Figures 5(a) and 5(b) show the microstructures of $\mathrm{FTO} / \mathrm{TiO}_{2} / \mathrm{CIS} / \mathrm{Al}$ and $\mathrm{FTO} / \mathrm{CIS} / \mathrm{TiO}_{2} / \mathrm{Al}$, respectively. As shown in Figure 5(a), the porous $\mathrm{TiO}_{2}$ layer has a composite structure with CIS nanocrystals. Therefore, the $\mathrm{p}-\mathrm{n}$ junction interface area, which is the photoelectron conversion region in the $\mathrm{TiO}_{2} / \mathrm{CIS}$ solar cells, becomes larger compared to the ordinary heterojunction structure, leading to an increase in efficiency. As shown in Figure 2, the optical absorption between $400 \mathrm{~nm}$ and $800 \mathrm{~nm}$ for the $\mathrm{TiO}_{2} / \mathrm{CIS}$ solar cell is higher than that of $\mathrm{CIS} / \mathrm{TiO}_{2}$ structure. The increase of the CIS layer thickness in the $\mathrm{TiO}_{2} / \mathrm{CIS}$ structure through the penetration of the CIS nanocrystals into the porous $\mathrm{TiO}_{2}$ layer would result in the increase of the optical absorption of $\mathrm{TiO}_{2} / \mathrm{CIS}$ solar cells. Charge separation for the $\mathrm{TiO}_{2} / \mathrm{CIS}$ solar cell would be higher from high optical absorption. However, the carrier recombination of electrons and holes would occur at the $\mathrm{FTO} / \mathrm{TiO}_{2}$ interface for the $\mathrm{TiO}_{2} / \mathrm{CIS}$ structure, and the energy conversion efficiency would not be improved by an increase of the $\mathrm{p}-\mathrm{n}$ heterojunction interface in the present work.

Energy level diagrams of $\mathrm{TiO}_{2} / \mathrm{CIS}$ and $\mathrm{CIS} / \mathrm{TiO}_{2}$ solar cells are summarized as shown in Figures 5(c) and 5(d), respectively. Previously reported values were used for the energy levels $[24,25]$. It has been reported that $V_{\mathrm{OC}}$ is nearly proportional to the bandgap of the semiconductors [26].

Compared to a Si semiconductor with an indirect transition band structure, the CIS with a direct transition band structure is the more suitable for the optical absorption property. In addition, the ultrathin film of the CIS layers could provide an efficient charge injection because of the high optical absorption. Although $\mathrm{Cu}\left(\mathrm{In}_{X}, \mathrm{Ga}_{1-X}\right) \mathrm{Se}_{2}$ (CIGS) has been mainly used as a p-type inorganic semiconductor for solar cells [27], CIS was applied instead of CIGS in the present work. Advantages of the present CIS are the lowcost reagent and the simple fabrication process. $\mathrm{TiO}_{2}$ and CIS have stable properties against sunlight, and prevent photodeterioration for the solar cells. CIS-based solar cells are expected to provide a long life time.

CIS-based solar cells prepared by a spin-coating method without vacuum evaporation were investigated in the present work. The low conversion efficiency of the present solar 


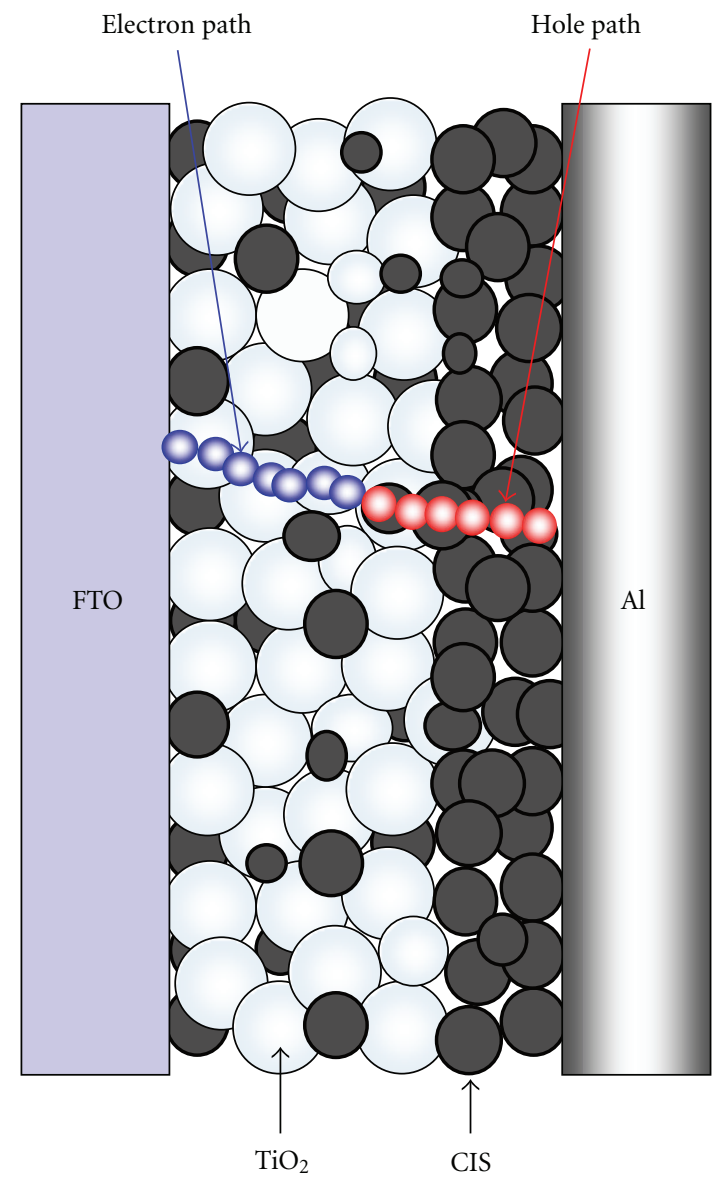

(a)

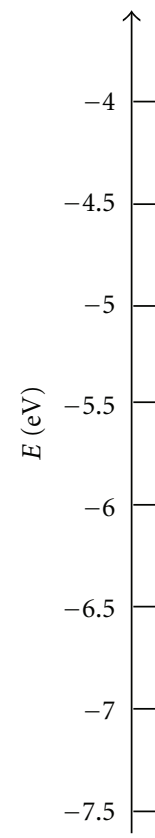

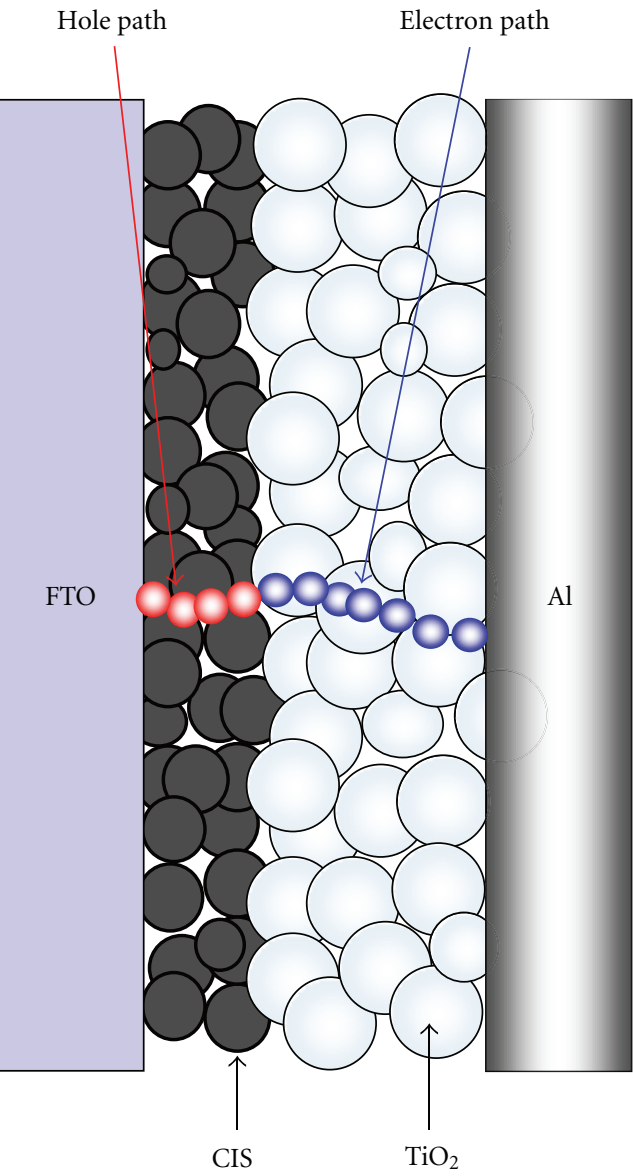

(b)

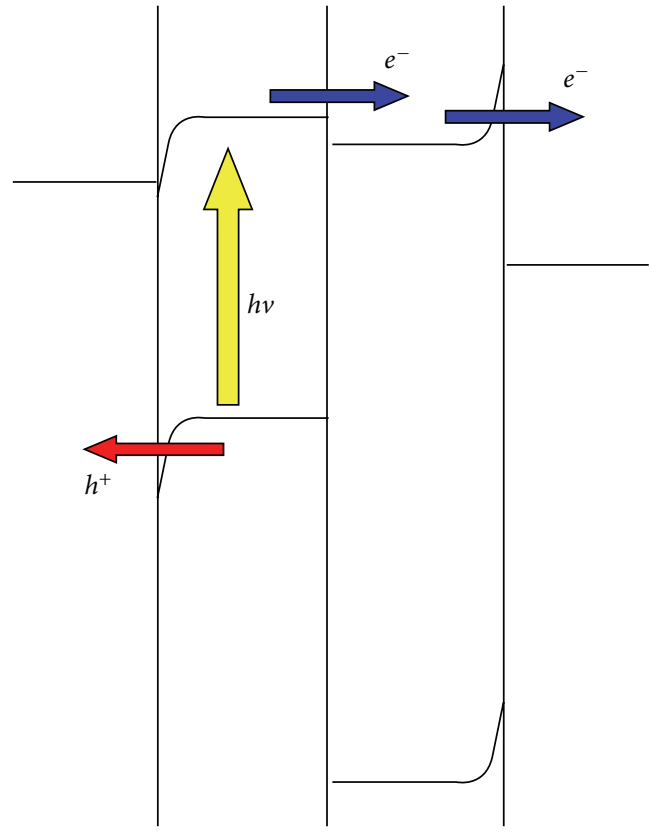

FTO

CIS

$\mathrm{TiO}_{2}$

$\mathrm{Al}$

(d)

Figure 5: Schematic microstructures of (a) $\mathrm{FTO} / \mathrm{TiO}_{2} / \mathrm{CIS} / \mathrm{Al}$ and (b) $\mathrm{FTO} / \mathrm{CIS} / \mathrm{TiO}_{2} / \mathrm{Al}$ solar cells. Energy level diagrams of (a) $\mathrm{TiO} / \mathrm{CIS}$ and (b) $\mathrm{CIS} / \mathrm{TiO}_{2}$ heterojunction solar cells. 


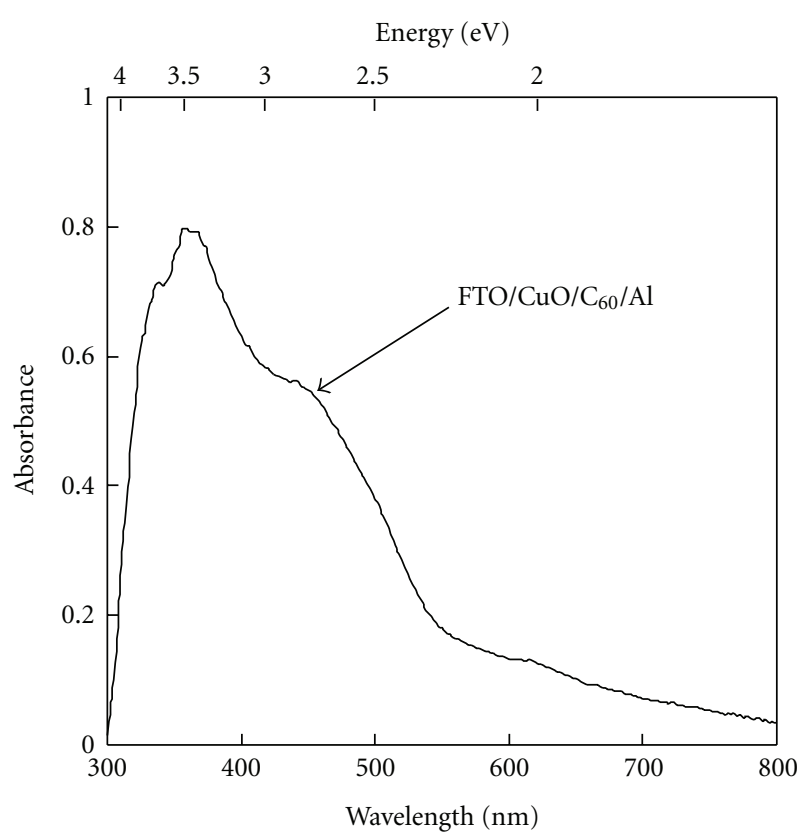

Figure 6: Optical absorption of $\mathrm{CuO} / \mathrm{C}_{60}$ heterojunction solar cell.

cells is due to presence of impure compounds in the active layer. The defects produced by inadequate crystals would cause carrier recombination. Optimization of the CIS microstructures can increase the efficiency of solar cells. There could be carrier recombination of electrons and holes at the rear surface of the n-type electrode (FTO). Solar cells with a buffer layer fabricated by addition of ultrathin $\mathrm{TiO}_{2}$ or $\mathrm{ZnO}$ n-type semiconductor layers between FTO and $\mathrm{TiO}_{2}$ have been reported [28, 29]. Energy conversion efficiency could be improved by addition of the buffer layers to inhibit carrier recombination at the contact surfaces.

3.2. $\mathrm{CuO} / \mathrm{C}_{60}$ Solar Cells. $J-V$ characteristics of the $\mathrm{CuO} / \mathrm{C}_{60}$ structures in the dark and under illumination were investigated. The photocurrent was observed under illumination, and the $\mathrm{CuO} / \mathrm{C}_{60}$ structure showed characteristic curves with short-circuit current and open-circuit voltage. Measured parameters of these solar cells are summarized in Table 1. A solar cell with a $\mathrm{CuO} / \mathrm{C}_{60}$ structure provided $\eta$ of $1.7 \times 10^{-4} \%$, FF of $0.25, J_{\mathrm{SC}}$ of $0.015 \mathrm{mAcm}^{-2}$, and $V_{\mathrm{OC}}$ of $0.045 \mathrm{~V}$.

Figure 6 shows the measured optical absorption of the $\mathrm{CuO} / \mathrm{C}_{60}$ solar cell. The absorption peaks around $350 \mathrm{~nm}$ in the $\mathrm{CuO} / \mathrm{C}_{60}$ structure were due to $\mathrm{CuO}$, and absorption peaks around $338 \mathrm{~nm}, 440 \mathrm{~nm}$, and $606 \mathrm{~nm}$ correspond to $\mathrm{C}_{60}$.

Figure 7 shows an X-ray diffraction pattern of the $\mathrm{CuO}$ thin films on glass substrates annealed at $300^{\circ} \mathrm{C}$ for 3 hours in air. Diffraction peaks corresponding to $\mathrm{CuO}$ were observed for the $\mathrm{CuO}$ thin film, which consisted of a tenorite phase with monoclinic system (space group of $\mathrm{C} 2 / \mathrm{c}$ and lattice parameters of $a=0.4653 \mathrm{~nm}, b=0.3410 \mathrm{~nm}$, $c=0.5108 \mathrm{~nm}$, and $\left.\beta=99.48^{\circ}\right)$. The crystallite size was estimated using Scherrer's equation. From the FWHM of the -111 peak, the crystallite size of $\mathrm{CuO}$ was determined

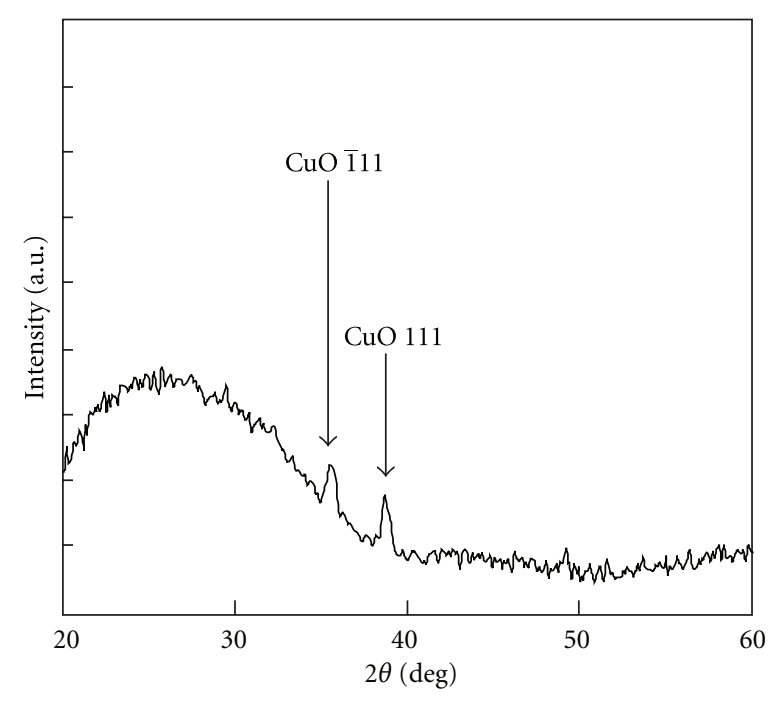

FIGURE 7: XRD patterns of $\mathrm{CuO}$ thin films annealed at $300^{\circ} \mathrm{C}$ for 3 hours in air.

to be $16.0 \mathrm{~nm}$. Figures $8(\mathrm{a})$ and $8(\mathrm{~b})$ show a TEM image and an electron diffraction pattern of the $\mathrm{CuO}$ thin film annealed at $300^{\circ} \mathrm{C}$, respectively. The TEM image indicated $\mathrm{CuO}$ nanocrystals with sizes of $10 \sim 20 \mathrm{~nm}$, which agree well with XRD results. Debye-Scherrer rings in Figure 8(b) indicate polycrystalline structures of $\mathrm{CuO}$.

Energy level diagram of $\mathrm{CuO} / \mathrm{C}_{60}$ solar cells is summarized as shown in Figure 9. Previously reported values were used for the energy levels $[20,30,31]$. Compared to the Si semiconductor with an indirect transition band structure, $\mathrm{CuO}$ with a direct transition bandgap is more suitable for the optical absorption property. Although $\mathrm{Cu}_{2} \mathrm{O}$ has been mainly used as a p-type oxide semiconductor for solar cells [14-17], $\mathrm{CuO}$ was applied instead of $\mathrm{Cu}_{2} \mathrm{O}$ in the present work. The advantages of the present $\mathrm{CuO}$ are low-cost reagent and the simple fabrication process.

CuO-based solar cells prepared by a spin-coating method without vacuum evaporation were investigated in the present work. The low conversion efficiency of the present solar cells would be due to carrier recombination by the defects produced by inadequate crystalline, and presence of $\mathrm{CuO}$ compounds with heterogeneous grain size in the active layer. Formation of the high-quality $\mathrm{CuO}$ thin films could increase the efficiency of solar cells.

3.3. $\mathrm{Cu}_{2} \mathrm{O}: \mathrm{C}_{60}$ Solar Cells. The $\mathrm{CuO} / \mathrm{C}_{60}$ solar cell was a heterojunction structure. To increase the interfacial area of $\mathrm{p}$-n junction, $\mathrm{Cu}_{2} \mathrm{O} / \mathrm{C}_{60}$ bulk heterojunction solar cells were prepared. The $J-V$ characteristics of the $\mathrm{Cu}_{2} \mathrm{O}: \mathrm{C}_{60}$ structure in the dark and under illumination were measured. The photocurrent was observed under illumination, and the $\mathrm{Cu}_{2} \mathrm{O}: \mathrm{C}_{60}$ structure showed photovoltaic properties. The measured parameters of the solar cells are summarized in Table 1. A solar cell with a $\mathrm{Cu}_{2} \mathrm{O}: \mathrm{C}_{60}$ structure provided $\eta$ of $4.3 \times 10^{-3} \%$, FF of $0.23, J_{\text {SC }}$ of $0.11 \mathrm{mAcm}^{-2}$ and $V_{\text {OC }}$ of $0.17 \mathrm{~V}$. 
TABLE 2: Comparison of copper oxide-based solar cells.

\begin{tabular}{lcccc}
\hline Sample & $\eta(\%)$ & Fabrication process & Annealing temperatures $\left({ }^{\circ} \mathrm{C}\right)$ & References \\
\hline Heterojunction $\mathrm{Cu}_{2} \mathrm{O} / \mathrm{ZnO}$ & 2.01 & Evaporation and annealing & 1000 & {$[1]$} \\
Heterojunction $\mathrm{CuO} / \mathrm{C}_{60}$ & $1.7 \times 10^{-4}$ & Spin coating & 300 & Present work \\
Bulk heterojunction $\mathrm{Cu}_{2} \mathrm{O}: \mathrm{C}_{60}$ & $4.3 \times 10^{-3}$ & Spin coating & 140 & Present work \\
\hline
\end{tabular}

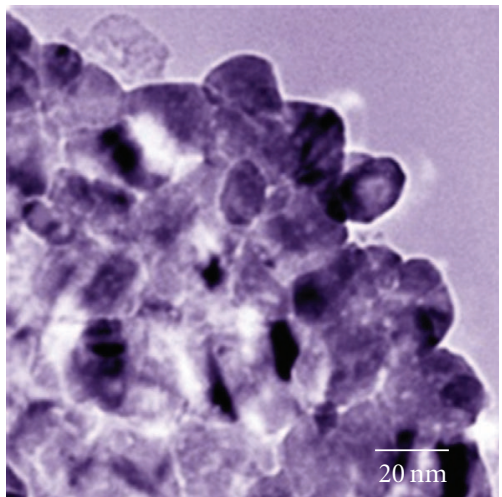

(a)

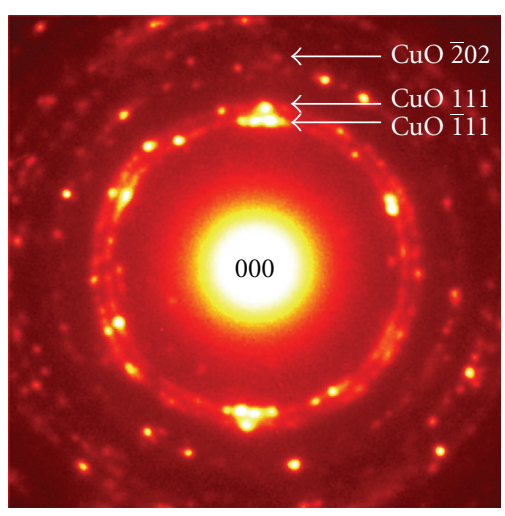

(b)

FIgURe 8: (a) TEM image and (b) electron diffraction pattern of $\mathrm{CuO}$ structure.

Figure 10 shows optical absorption of the $\mathrm{Cu}_{2} \mathrm{O}: \mathrm{C}_{60}$ solar cells. An absorption peak around $324 \mathrm{~nm}$ for the $\mathrm{Cu}_{2} \mathrm{O}: \mathrm{C}_{60}$ structure is due to $\mathrm{Cu}_{2} \mathrm{O}$, and the absorption peak around $362 \mathrm{~nm}$ and $476 \mathrm{~nm}$ corresponds to $\mathrm{C}_{60}$.

Microstructures of the $\mathrm{Cu}_{2} \mathrm{O}: \mathrm{C}_{60}$ thin films were investigated by XRD, as shown in Figure 11. Diffraction peaks corresponding to $\mathrm{Cu}_{2} \mathrm{O}$ and $\mathrm{C}_{60}$ were observed for the $\mathrm{Cu}_{2} \mathrm{O}: \mathrm{C}_{60}$ thin film, and they consisted of a cuprite phase with cubic system (space group of $\mathrm{Pn} 3 \mathrm{~m}$ and a lattice parameter of $a=0.4250 \mathrm{~nm}$ ), and a $\mathrm{C}_{60}$ phase with cubic system (space group of Fm3m and a lattice parameter of $a$ $=1.4166 \mathrm{~nm})$. The crystallite sizes of $\mathrm{Cu}_{2} \mathrm{O}$ and $\mathrm{C}_{60}$ were determined to be $7.2 \mathrm{~nm}$ and $25.7 \mathrm{~nm}$, respectively.

Figures 12(a) and 12(b) show a TEM image and a selected area diffraction pattern of the $\mathrm{Cu}_{2} \mathrm{O}: \mathrm{C}_{60}$ thin film annealed at $100^{\circ} \mathrm{C}$, respectively. The TEM image indicated aggregated $\mathrm{Cu}_{2} \mathrm{O}$ nanocrystals with sizes of $10 \sim 20 \mathrm{~nm}$. Line broadening of the Debye-Scherrer rings in Figure 12(b) indicates

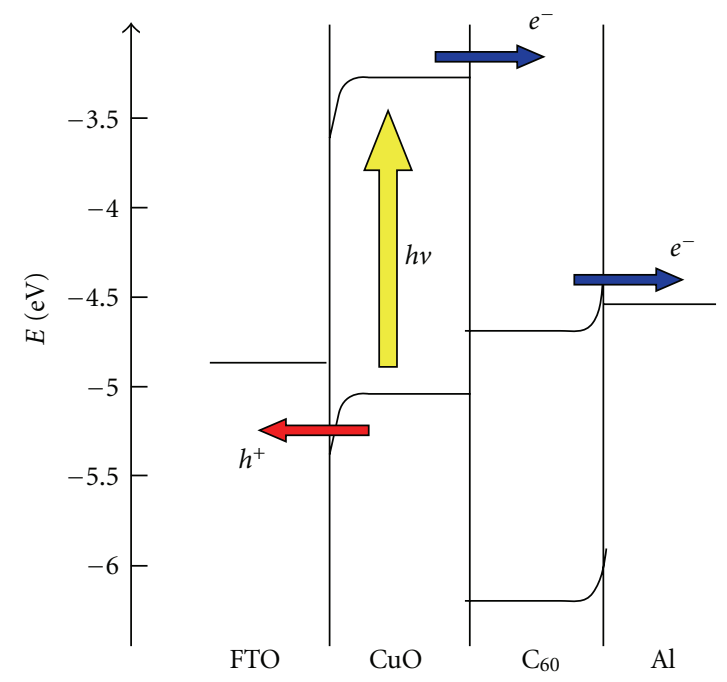

Figure 9: Energy level diagram of $\mathrm{FTO} / \mathrm{CuO} / \mathrm{C}_{60} / \mathrm{Al}$ heterojunction solar cells.

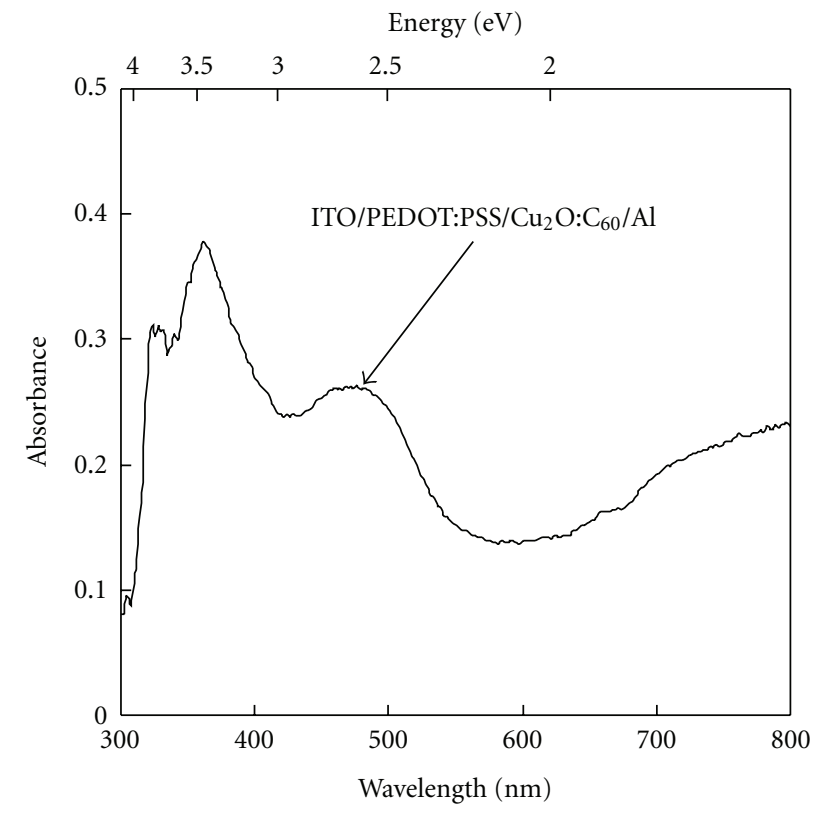

FIGURE 10: Optical absorption of $\mathrm{Cu}_{2} \mathrm{O}: \mathrm{C}_{60}$ bulk heterojunction solar cells.

nanocrystal structures of $\mathrm{Cu}_{2} \mathrm{O} . \mathrm{C}_{60}$ peaks [32] were not observed in this pattern, which would be due to dispersion of $\mathrm{C}_{60}$ crystals. Optimization of the nanocomposite structure with $\mathrm{Cu}_{2} \mathrm{O}$ and $\mathrm{C}_{60}$ would increase the efficiencies of the solar cells. 


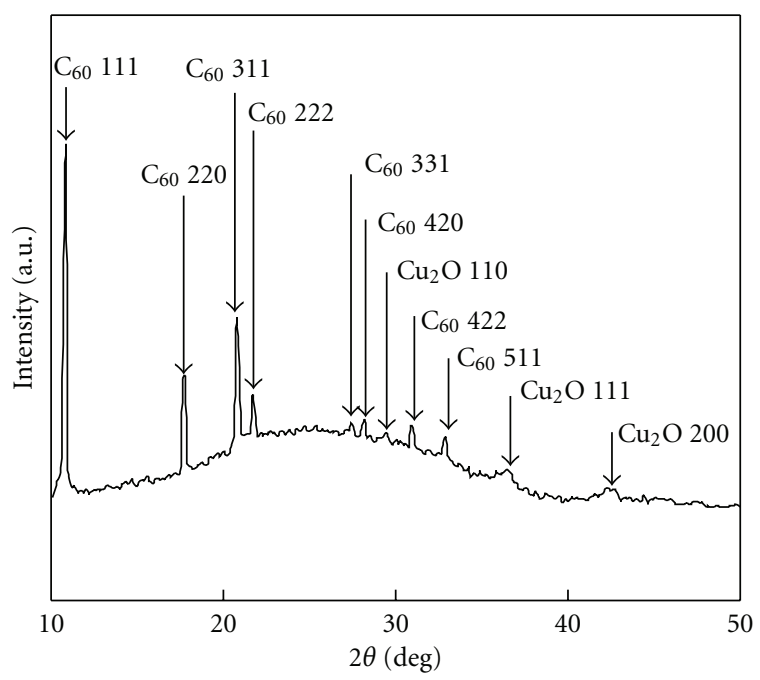

FIGURE 11: XRD pattern of $\mathrm{Cu}_{2} \mathrm{O}: \mathrm{C}_{60}$ thin film.

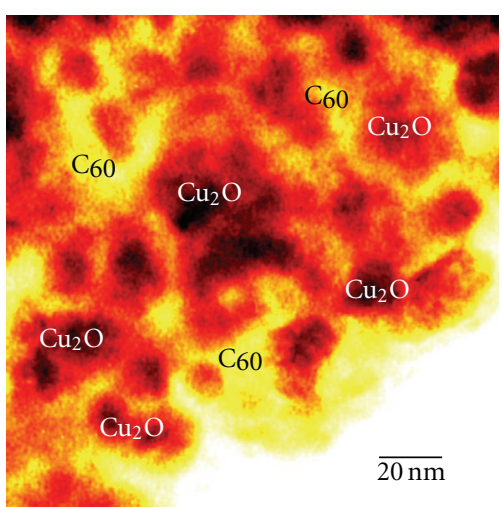

(a)

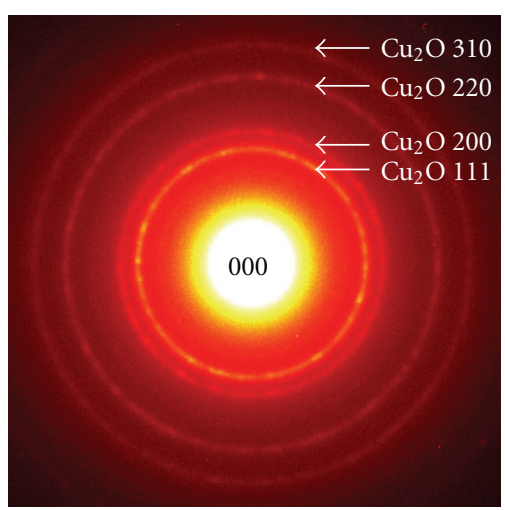

(b)

FIGURE 12: (a) TEM image and (b) electron diffraction pattern of $\mathrm{Cu}_{2} \mathrm{O}: \mathrm{C}_{60}$ structure.

Energy level diagram of the $\mathrm{Cu}_{2} \mathrm{O}: \mathrm{C}_{60}$ solar cell is summarized as shown in Figure 13. Previously reported values were used for the energy levels $[11,31,33] . \mathrm{Cu}_{2} \mathrm{O}$ with a direct transition bandgap is more suitable for the optical absorption property compared to $\mathrm{Si}$. Although $\mathrm{ZnO}$ has been mainly used as an n-type oxide semiconductor for solar cells

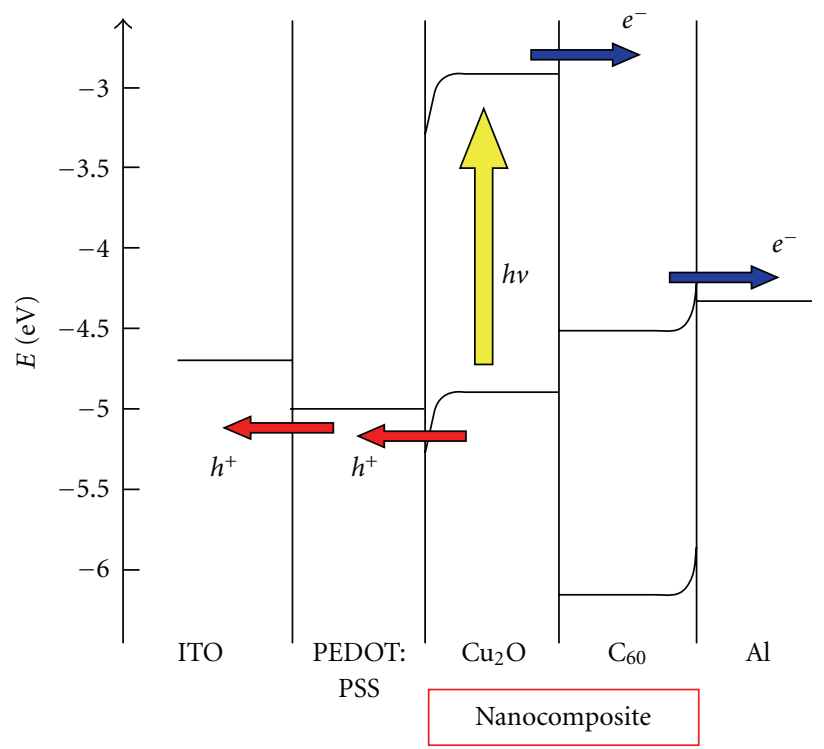

FIGURE 13: Energy level diagram of ITO/PEDOT:PSS/ $\mathrm{Cu}_{2} \mathrm{O}: \mathrm{C}_{60} / \mathrm{Al}$ bulk heterojunction solar cells.

[14-17], $\mathrm{C}_{60}$ was applied instead of $\mathrm{ZnO}$ in the present work. Advantages of the present $\mathrm{C}_{60}$ are a good acceptor for solar cells and the simple fabrication process.

Compared to previously reported $\mathrm{Cu}_{2} \mathrm{O}$-based heterojunction solar cells [14], copper oxide-based bulk heterojunction and heterojunction solar cells prepared by a spincoating method without a vacuum system were investigated in the present work, as listed in Table 2. The present copper oxide-based bulk heterojunction and heterojunction solar cells have simple fabrication process and good cost performance.

The low conversion efficiency of the present solar cells would be due to aggregation of $\mathrm{Cu}_{2} \mathrm{O}$ nanoparticle in the active layer, which would cause carrier recombination. Formation of the $\mathrm{Cu}_{2} \mathrm{O}: \mathrm{C}_{60}$ thin films with homogeneous distribution of $\mathrm{Cu}_{2} \mathrm{O}$ nanoparticles could increase the efficiency of solar cells.

\section{Conclusions}

Copper system compound semiconductor solar cells were produced and characterized. A device based on the $\mathrm{CIS} / \mathrm{TiO}_{2}$ structure provided $\eta$ of $1.5 \times 10^{-5} \%$, FF of $0.25, J_{\mathrm{SC}}$ of $6.0 \times 10^{-3} \mathrm{~mA} / \mathrm{cm}^{2}$, and $V_{\text {OC }}$ of $1.0 \times 10^{-2} \mathrm{~V}$, which showed better performance compared to that of a device based on the $\mathrm{TiO}_{2} / \mathrm{CIS}$ structure. The devices based on the $\mathrm{CuO} / \mathrm{C}_{60}$ and $\mathrm{Cu}_{2} \mathrm{O}: \mathrm{C}_{60}$ structures were fabricated by a spin-coating method which provided $\eta$ of $1.7 \times 10^{-4} \%$ and $4.3 \times 10^{-3} \%$, FF of 0.25 and $0.23, J_{\text {SC }}$ of $0.015 \mathrm{mAcm}^{-2}$ and $0.11 \mathrm{mAcm}^{-2}$, and $V_{\mathrm{OC}}$ of $0.045 \mathrm{~V}$ and $0.17 \mathrm{~V}$, respectively. X-ray diffraction analysis indicated the formation of $\mathrm{CIS}, \mathrm{CuO}$, and $\mathrm{Cu}_{2} \mathrm{O}$ nanocrystal structures, respectively.

Energy level diagrams of $\mathrm{CIS} / \mathrm{TiO}_{2}, \mathrm{CuO} / \mathrm{C}_{60}$, and $\mathrm{Cu}_{2} \mathrm{O}: \mathrm{C}_{60}$ solar cells were proposed. Separated holes could transfer from the valence band of the copper system 
compound semiconductors to the transparent conducting oxide electrodes, and separated electrons could transfer from the conduction band of the copper system compound semiconductors to the $\mathrm{Al}$ electrodes, respectively.

Formation of the high-quality in active layers with inorganic nanoparticles would improve the efficiencies of the solar cells. The bulk heterojunction structure with dispersed inorganic nanoparticles in present work was effective for the improvement of current density.

\section{Acknowledgment}

This paper is partly supported by Takahashi Industrial and Economic Research Foundation.

\section{References}

[1] T. Ohashi, Y. Hashimoto, and K. Ito, "Solar cells with $\mathrm{Cu}\left(\mathrm{In}_{1-x} \mathrm{Ga}_{x}\right) \mathrm{S}_{2}$ thin films prepared by sulfurization," Solar Energy Materials and Solar Cells, vol. 67, no. 1-4, pp. 225-230, 2001.

[2] M. Nanu, J. Schoonman, and A. Goossens, "Solar-energy conversion in $\mathrm{TiO}_{2} / \mathrm{CuInS}_{2}$ nanocomposites," Advanced Functional Materials, vol. 15, no. 1, pp. 95-100, 2005.

[3] F. Lenzmann, M. Nanu, O. Kijatkina, and A. Belaidi, "Substantial improvement of the photovoltaic characteristics of $\mathrm{TiO}_{2} / \mathrm{CuInS}_{2}$ interfaces by the use of recombination barrier coatings," Thin Solid Films, vol. 451-452, pp. 639-643, 2004.

[4] T. T. John, M. Mathew, C. S. Kartha, K. P. Vijayakumar, T. Abe, and Y. Kashiwaba, "CuInS ${ }_{2} / \operatorname{In}_{2} \mathrm{~S}_{3}$ thin film solar cell using spray pyrolysis technique having 9.5\% efficiency," Solar Energy Materials and Solar Cells, vol. 89, no. 1, pp. 27-36, 2005.

[5] H.-J. Koo, Y. J. Kim, Y. H. Lee, W. I. Lee, K. Kim, and N.-G. Park, "Nano-embossed hollow spherical $\mathrm{TiO}_{2}$ as bifunctional material for high-efficiency dye-sensitized solar cells," Advanced Materials, vol. 20, no. 1, pp. 195-199, 2008.

[6] G. Yu and A. J. Heeger, "Charge separation and photo-voltaic conversion in polymer composites with internal donor/ acceptor heterojunctions," Journal of Applied Physics, vol. 78, no. 7, pp. 4510-4515, 1995.

[7] F. Padinger, R. S. Rittberger, and N. S. Sariciftci, "Effects of postproduction treatment on plastic solar cells," Advanced Functional Materials, vol. 13, no. 1, pp. 85-88, 2003.

[8] Y. Hayashi, I. Yamada, S. Takagi, A. Takasu, T. Soga, and T. Jimbo, "Influence of structure and $\mathrm{C}_{60}$ composition on properties of blends and bilayers of organic donor-acceptor polymer/ $\mathrm{C}_{60}$ photovoltaic devices," Japanese Journal of Applied Physics, vol. 44, no. 3, pp. 1296-1300, 2005.

[9] S.-Y. Lee and B.-O. Park, "CuInS 2 thin films deposited by sol-gel spin-coating method," Thin Solid Films, vol. 516, no. 12, pp. 3862-3864, 2008.

[10] T. Todorov, E. Cordoncillo, J. F. Sánchez-Royo, J. Carda, and P. Escribano, "CuInS $S_{2}$ films for photovoltaic applications deposited by a low-cost method," Chemistry of Materials, vol. 18, no. 13, pp. 3145-3150, 2006.

[11] T. Oku, S. Nagaoka, A. Suzuki et al., "Formation and characterization of polymer/fullerene bulk heterojunction solar cells," Journal of Physics and Chemistry of Solids, vol. 69, no. 5-6, pp. 1276-1279, 2008.
[12] T. Oku, T. Noma, A. Suzuki, K. Kikuchi, and S. Kikuchi, "Fabrication and characterization of fullerene/porphyrin bulk heterojunction solar cells," Journal of Physics and Chemistry of Solids, vol. 71, no. 4, pp. 551-555, 2010.

[13] R. Motoyoshi, A. Suzuki, K. Kikuchi, and T. Oku, "Formation and characterization of copper tetrakis (4-cumylphenoxy) phthalocyanine:perylene solar cells," Synthetic Metals, vol. 159, no. 13, pp. 1345-1348, 2009.

[14] A. Mittiga, E. Salza, F. Sarto, M. Tucci, and R. Vasanthi, "Heterojunction solar cell with $2 \%$ efficiency based on a $\mathrm{Cu}_{2} \mathrm{O}$ substrate," Applied Physics Letters, vol. 88, no. 16, Article ID 163502, 2006.

[15] M. Izaki, T. Shinagawa, K.-T. Mizuno, Y. Ida, M. Inaba, and A. Tasaka, "Electrochemically constructed $\mathrm{p}-\mathrm{Cu}_{2} \mathrm{O} / \mathrm{n}-\mathrm{ZnO}$ heterojunction diode for photovoltaic device," Journal of Physics D, vol. 40, no. 11, article no. 010, pp. 3326-3329, 2007.

[16] S. S. Jeong, A. Mittiga, E. Salza, A. Masci, and S. Passerini, "Electrodeposited $\mathrm{ZnO} / \mathrm{Cu}_{2} \mathrm{O}$ heterojunction solar cells," Electrochimica Acta, vol. 53, no. 5, pp. 2226-2231, 2008.

[17] M. Izaki, K.-T. Mizuno, T. Shinagawa, M. Inaba, and A. Tasaka, "Photochemical construction of photovoltaic device composed of p-copper(I) oxide and n-zinc oxide," Journal of the Electrochemical Society, vol. 153, no. 9, pp. C668-C672, 2006.

[18] S. Anandan, X. Wen, and S. Yang, "Room temperature growth of $\mathrm{CuO}$ nanorod arrays on copper and their application as a cathode in dye-sensitized solar cells," Materials Chemistry and Physics, vol. 93, no. 1, pp. 35-40, 2005.

[19] P. Raksa, S. Nilphai, A. Gardchareon, and S. Choopun, "Copper oxide thin film and nanowire as a barrier in $\mathrm{ZnO}$ dye-sensitized solar cells," Thin Solid Films, vol. 517, no. 17, pp. 4741-4744, 2009.

[20] A. Takeda, T. Oku, A. Suzuki, K. Kikuchi, and S. Kikuchi, "Fabrication and characterization of inorganic-organic hybrid solar cells based on $\mathrm{CuInS}_{2}$," Nippon Seramikkusu Kyokai Gakujutsu Ronbunshi/Journal of the Ceramic Society of Japan, vol. 117, no. 1369, pp. 967-969, 2009.

[21] L. Armelao, D. Barreca, M. Bertapelle, G. Bottaro, C. Sada, and E. Tondello, "A sol-gel approach to nanophasic copper oxide thin films," Thin Solid Films, vol. 442, no. 1-2, pp. 48-52, 2003.

[22] L. N. Lewis, J. L. Spivack, S. Gasaway et al., "A novel UVmediated low-temperature sintering of $\mathrm{TiO}_{2}$ for dye-sensitized solar cells," Solar Energy Materials and Solar Cells, vol. 90, no. 7-8, pp. 1041-1051, 2006.

[23] N.-G. Park, M. G. Kang, K. S. Ryu, K. M. Kim, and S. H. Chang, "Photovoltaic characteristics of dye-sensitized surface-modified nanocrystalline $\mathrm{SnO}_{2}$ solar cells," Journal of Photochemistry and Photobiology A, vol. 161, no. 2-3, pp. 105-110, 2004.

[24] E. Arici, N. S. Sariciftci, and D. Meissner, "Hybrid solar cells based on nanoparticles of $\mathrm{CuInS}_{2}$ in organic matrices," Advanced Functional Materials, vol. 13, no. 2, pp. 165-170, 2003.

[25] Q. Qiao and J. T. McLeskey Jr., "Water-soluble polythiophenenanocrystalline $\mathrm{TiO}_{2}$ solar cells," Applied Physics Letters, vol. 86, no. 15, Article ID 153501, 3 pages, 2005.

[26] M. A. Green, K. Emery, D. L. King, Y. Hishikawa, and W. Warta, "Solar cell efficiency tables (version 28)," Progress in Photovoltaics: Research and Applications, vol. 14, no. 5, pp. 455-461, 2006.

[27] M. A. Contreras, K. Ramanathan, J. AbuShama et al., "Diode characteristics in state-of-the-art $\mathrm{ZnO} / \mathrm{CdS} / \mathrm{Cu}\left(\mathrm{In}_{1-x} \mathrm{Ga}_{x}\right) \mathrm{Se}_{2}$ solar cells," Progress in Photovoltaics: Research and Applications, vol. 13, no. 3, pp. 209-216, 2005. 
[28] M. Valdés, M. A. Frontini, M. Vázquez, and A. Goossens, "Low-cost 3D nanocomposite solar cells obtained by electrodeposition of CuInSe, $e_{2}$, Applied Surface Science, vol. 254, no. 1, pp. 303-307, 2007.

[29] M. Krunks, A. Katerski, T. Dedova, I. Oja Acik, and A. Mere, "Nanostructured solar cell based on spray pyrolysis deposited ZnO nanorod array," Solar Energy Materials and Solar Cells, vol. 92, no. 9, pp. 1016-1019, 2008.

[30] K. Nakaoka, J. Ueyama, and K. Ogura, "Photoelectrochemical behavior of electrodeposited $\mathrm{CuO}$ and $\mathrm{Cu}_{2} \mathrm{O}$ thin films on conducting substrates," Journal of the Electrochemical Society, vol. 151, no. 10, pp. C661-C665, 2004.

[31] F. Caballero-Briones, J. M. Artés, I. Díez-Pérez, P. Gorostiza, and F. Sanz, "Direct observation of the valence band edge by in situ ECSTM-ECTS in p-type $\mathrm{Cu}_{2} \mathrm{O}$ layers prepared by copper anodization," Journal of Physical Chemistry C, vol. 113, no. 3, pp. 1028-1036, 2009.

[32] V. P. Dravid, S. Liu, and M. M. Kappes, "Transmission electron microscopy of chromatographically purified solid state $\mathrm{C}_{60}$ and $\mathrm{C}_{70}$," Chemical Physics Letters, vol. 185, no. 1-2, pp. 75-81, 1991.

[33] C.-W. Chu, V. Shrotriya, G. Li, and Y. Yang, "Tuning acceptor energy level for efficient charge collection in copperphthalocyanine-based organic solar cells," Applied Physics Letters, vol. 88, no. 15, Article ID 153504, 2006. 

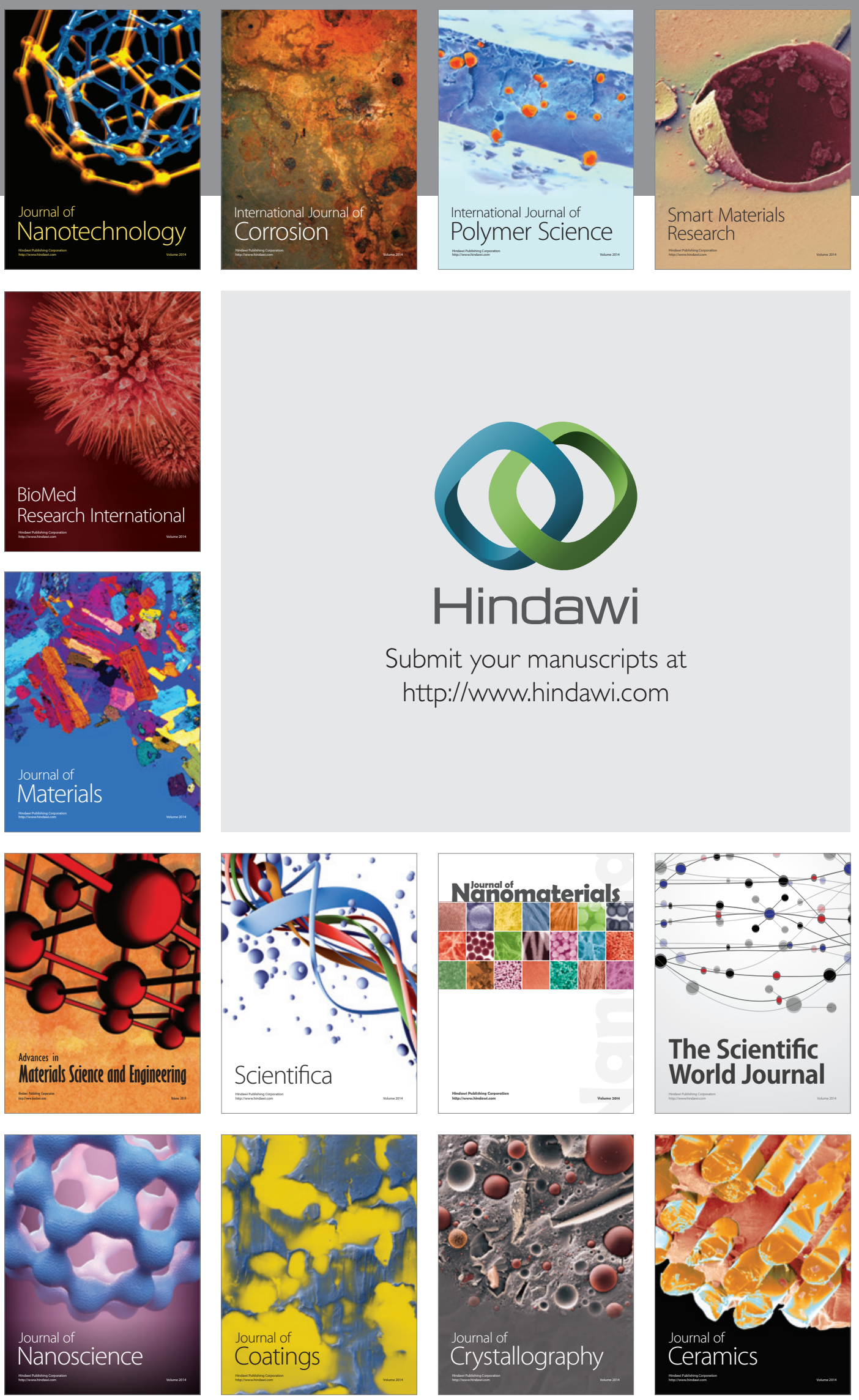

The Scientific World Journal

Submit your manuscripts at

http://www.hindawi.com

\section{World Journal}

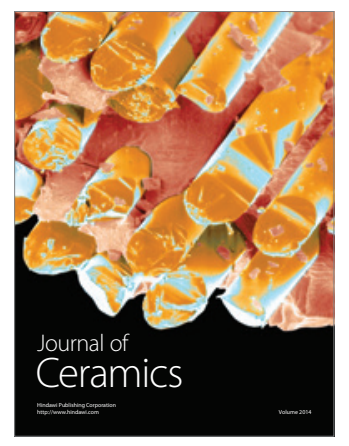

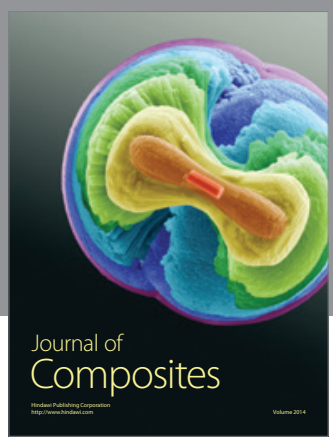
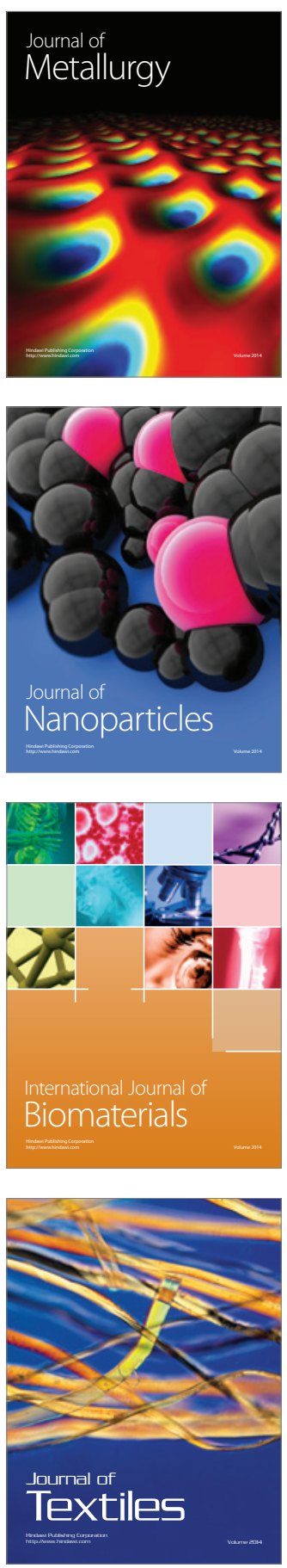